\title{
вмJ Global Health The case for developing a cohesive systems approach to research across unhealthy commodity industries
}

Cécile Knai (D) , , ${ }^{1,2}$ Mark Petticrew, ${ }^{1,2}$ Simon Capewell, ${ }^{3}$ Rebecca Cassidy, ${ }^{4}$ Jeff Collin, ${ }^{2,5}$ Steven Cummins, ${ }^{6}$ Elizabeth Eastmure, ${ }^{1}$ Patrick Fafard, ${ }^{7}$ Niamh Fitzgerald, ${ }^{2,8}$ Anna B Gilmore, ${ }^{2,9}$ Ben Hawkins, ${ }^{1}$ Jørgen Dejgård Jensen, ${ }^{10}$ Srinivasa Vittal Katikireddi, ${ }^{11}$ Nason Maani (D) , ${ }^{1,2,12}$ Nicholas Mays, ${ }^{1}$ Modi Mwatsama, ${ }^{13}$ Rima Nakkash, ${ }^{14}$ Jim F Orford, ${ }^{15,16}$ Harry Rutter, ${ }^{17}$ Natalie Savona, ${ }^{1}$ May C I van Schalkwyk, ${ }^{1}$ Heide Weishaar ${ }^{18}$

To cite: Knai C, Petticrew M, Capewell S, et al. The case for developing a cohesive systems approach to research across unhealthy commodity industries. BMJ Global Health 2021;6:e003543. doi:10.1136/ bmjgh-2020-003543

\section{Handling editor Eduardo Gómez}

- Additional material is published online only. To view, please visit the journal online (http://dx.doi.org/10.1136/ bmjgh-2020-003543).

Received 25 July 2020 Revised 22 October 2020 Accepted 11 November 2020

Check for updates

C Author(s) (or their employer(s)) 2021. Re-use permitted under CC BY-NC. No commercial re-use. See rights and permissions. Published by BMJ.

For numbered affiliations see end of article.

Correspondence to Professor Cécile Knai; cecile.knai@Ishtm.ac.uk

\section{ABSTRACT}

Objectives Most non-communicable diseases are preventable and largely driven by the consumption of harmful products, such as tobacco, alcohol, gambling and ultra-processed food and drink products, collectively termed unhealthy commodities. This paper explores the links between unhealthy commodity industries (UCls), analyses the extent of alignment across their corporate political strategies, and proposes a cohesive systems approach to research across UCls.

Methods We held an expert consultation on analysing the involvement of UCls in public health policy, conducted an analysis of business links across UCls, and employed taxonomies of corporate political activity to collate, compare and illustrate strategies employed by the alcohol, ultra-processed food and drink products, tobacco and gambling industries.

Results There are clear commonalities across UCIs' strategies in shaping evidence, employing narratives and framing techniques, constituency building and policy substitution. There is also consistent evidence of business links between UCls, as well as complex relationships with government agencies, often allowing UCls to engage in policy-making forums. This knowledge indicates that the role of all UCls in public health policy would benefit from a common approach to analysis. This enables the development of a theoretical framework for understanding how UCls influence the policy process. It highlights the need for a deeper and broader understanding of conflicts of interests and how to avoid them; and a broader conception of what constitutes strong evidence generated by a wider range of research types.

Conclusion UCls employ shared strategies to shape public health policy, protecting business interests, and thereby contributing to the perpetuation of non-communicable diseases. A cohesive systems approach to research across UCls is required to deepen shared understanding of this complex and interconnected area and also to inform a more effective and coherent response.

\section{Key questions}

What is already known?

- Most premature deaths from non-communicable disease are preventable and largely caused by the consumption of the products of unhealthy commodity industries (UCls), including tobacco, alcohol, gambling and ultra-processed food and drink products.

- Public health governance is characterised by an increasingly diversified and complex system of decision-making with close relationships between state and UCls.

- Evidence indicates that UCls have deliberately and collectively pushed for these forms of governance in order to prevent public health policies that might threaten profits.

What are the new findings?

- There is a convergence of strategic approaches across UCls aimed at shaping public health policy.

- There is evidence of business links between UCls, complex inter-relationships between the public and private sectors, and across UCls, and commonalities in corporate political strategies.

What do the new findings imply?

- A systems approach is required to study UCls, the linkages between them and the way in which they collectively influence policy.

\section{INTRODUCTION}

Over $70 \%$ of premature deaths worldwide can be attributed to non-communicable diseases (NCDs), notably cardiovascular disease, cancer, diabetes, dementia, chronic respiratory disease, mental health problems and related conditions such as obesity. The majority of premature NCD deaths are preventable, being principally caused by the consumption of the products of the tobacco, alcohol, gambling and ultra-processed food 
and drink products industries. ${ }^{1-3}$ These have been collectively referred to as the unhealthy commodity industries (UCIs), defined as industries or groups of corporations where a significant share of their product portfolio comprises unhealthy commodities with high profit margins aimed at, and easily accessible to, large numbers of consumers. ${ }^{4-6}$ The gambling industry has received less attention than other UCIs as a driver of NCDs, but research is expanding rapidly showing that gambling is associated not just with alcohol and drug problems, but also depression and anxiety. ${ }^{2}{ }^{3} 7-9$ The harm from gambling is now comparable with that associated with alcohol misuse in high-income countries. ${ }^{10}$ The United Nations (UN) and the World Health Organization (WHO) have coordinated global commitments to NCD prevention over recent decades. ${ }^{11}$ However, implementation of effective solutions remains limited. A key barrier has been the continued close involvement of UCIs in public health policy-making. ${ }^{12} 13$

Public health governance is broadly defined as the set of functions ensuring authority (including scientific knowledge), resources, policy development, continuous evaluation and improvement, and effective collaboration on public health issues. ${ }^{14}$ This policy arena is characterised by an increasingly diversified and complex system of decision-making, ${ }^{13}$ with an often symbiotic relationship between states and non-state actors, including corporations. ${ }^{15}$ One rationale for the involvement of UCIs in public health governance is that those affected by policies should be allowed to contribute to their formulation. ${ }^{16}$ This may be problematic for a number of reasons. First, it is based on the premise that the power to influence policy debates is reasonably equally distributed across interest groups; this cannot be assumed where multinational corporations have vast influence, often with annual turnovers exceeding those of many national economies. ${ }^{17}$ Second, evidence indicates that corporations whose products are damaging to health have deliberately and collectively pushed for these forms of governance, encouraging policy-making structures that embed corporate influence and a reliance on corporate evidence specifically in order to prevent public health policies that might threaten profits. ${ }^{18-20}$ Evidence also shows how they have used those systems, for example, to overwhelm public consultations and to submit misleading evidence. ${ }^{21}{ }^{22}$ Any potential benefits of UCI involvement in public health policy are therefore strongly contested due to the differences between their corporate interests and public health goals. ${ }^{4}$

This study sits within the overarching domain of, and contributes to research on, the 'commercial determinants of health', variously defined as adverse health impacts attributable to commercial activities and strategies employed by UCIs to promote products which can damage health. ${ }^{23-25}$

There is growing evidence of convergence of strategic approaches between UCIs themselves, ${ }^{26}$ and the need for a systems approach to conducting research on UCIs' influence of public health policy. Doing so would conceptualise poor health as the result of many factors-such as UCIs' shaping of policy-as interconnected elements working together to bring about change throughout the system. ${ }^{28}$ A complex systems approach to understanding the commercial determinants of health draws upon a range of methods to design, implement and evaluate interventions at a systems level to improve public health ${ }^{29}$ it can help explore how UCIs position themselves in the complex process of public health decisionmaking and how they legitimise their presence there. It can encourage public health researchers to integrate mixed methods from a variety of sources and disciplines including quantitative and qualitative traditions. ${ }^{30} 31 \mathrm{~A}$ systems approach to research on UCIs offers an analytical framework within which to explore not only the conditions and factors shaping the commercial determinants of health, but also, importantly, the way in which these factors relate to each other and how they generate environments which negatively affect health. ${ }^{25}$

This paper explores the links between UCIs, analyses the extent of alignment across their corporate political strategies and proposes a cohesive systems approach to research across UCIs.

\section{METHODS}

First, an international meeting of researchers was organised in February 2016 on Analysing the Involvement of Unhealthy Commodity Industries in Public Health Policy'. The event convened 50 researchers in the areas of food, alcohol, tobacco and gambling research from 20 academic institutions representing a range of relevant disciplines. ${ }^{32}$ One of the conclusions of the meeting was the acknowledgement of a shared experience in UCI research, highlighting common challenges, prompting a move out of 'disciplinary bunkers ${ }^{33}$ and the formulation of a more integrated research agenda. Another important output of the meeting was agreement on the need for appropriate conceptual and methodological tools for analysing the role of UCIs in public health, such as complex systems approaches. This paper is written as a response to the aims and challenges set out during that initial event.

Second, we conducted a narrative review to analyse the business links between UCIs, defined here as investments, either ownership of companies or strategic investments such as equity stakes in a company. We focused on the activities of prominent alcohol, ultra-processed food and drink products, tobacco and gambling industries, while acknowledging that neither the list of UCIs, nor the literature reported, is exhaustive. We analysed publicly available information authored by, or on the subject of, business links between UCIs, sourced from peer-reviewed and grey literature. We employed terms reflecting UCIs (for example alcohol, food), terms related to network links between corporations and across industries (such as connection, relationship, partnership, 'revolving doors' 
and 'interlocking directorates') to guide the search. ${ }^{26} \mathrm{We}$ conducted searches on company websites themselves to characterise and identify links between businesses. Due to the number of potential links it was not possible to produce an exhaustive list of links.

Third, we searched for taxonomies of corporate political activities (CPAs) employed by UCIs. The CPAs of the UCIs are typically designed to support market goals by leveraging political and social influence to affect policy. ${ }^{23-41}$ CPAs are defined as corporate strategies to shape government policy in ways favourable to them ${ }^{42}$; their use by individual UCIs has been extensively documented. ${ }^{38-40} 4344$ We referred to these taxonomies to collate and compare CPAs across the four selected UCIs, to identify the degree of similarity between them. The taxonomies of corporate political strategies that we drew on in this research were themselves developed from systematic reviews of large bodies of evidence, starting with the early versions of the tobacco ${ }^{39}$ and alcohol $^{38}$ taxonomies, followed by taxonomies of food industry $\mathrm{CPA}^{45}$ and combined with other work. ${ }^{46}$ The systematic literature reviews and resulting taxonomies thus enabled comparisons of CPA between UCIs, suggesting similarity in tactics. ${ }^{38} 3943$ We used the taxonomies to code our examples, seeking evidence of commonalities across industries. The included examples are intended to be illustrative but not exhaustive.

\section{RESULTS}

\section{Business links across UCls}

There is consistent evidence of business links across UCIs. ${ }^{26} 35364147-49$ These links can be expressed as business investments, ownership of companies, strategic investments such as equity stakes in a company, or other affiliations such as via presence on a board of directors (interlocking directorates). The benefits achieved from these links include the establishment of synergies across marketing strategies and sharing of data on consumer characteristics. ${ }^{50}$

For example, Nguyen et al report on the tobacco industry's early diversification into food and drink, highlighting Philip Morris' and RJ Reynolds' stakes in the sugar-sweetened beverage market, acquiring or developing brands such as Kool Aid from the 1960s. ${ }^{50}$ Currently, the tobacco company Altria (formerly Philip Morris Companies) owns Ste Michelle Wine Estates ${ }^{51}$ and has a considerable stake (about 10\%) in alcohol giant ABInBev. ${ }^{52}$ In 2016, ABInBev acquired the South African brewer SABMiller, which until recently bottled and distributed Coca-Cola across many African countries. ${ }^{51}{ }^{53} \mathrm{ABInBev}$ still owns a company which distributes Pepsico products including Pepsi, 7Up and Gatorade. ${ }^{54}$ Since 2018 Altria has also owned a 45\% stake in Cronos Group, a cannabis company ${ }^{55}$ Similarly, British American Tobacco is a corporate partner of Aristocrat Leisure, a major poker machine manufacturer, and Tabcorp, a major gambling operator. ${ }^{56}$ Many of these business links also take the form of 'interlocking directorates', when a person affiliated with one organisation sits on the board of directors of another. ${ }^{57} \mathrm{~A}$ recent social network analysis of the links across the top six transnational manufacturers of tobacco, alcohol and ultra-processed food and drink products found that alcohol companies provided bridges between tobacco and food companies, and highlighted how these links bolstered influence with political elites and health agencies. ${ }^{26}$

\section{'Revolving door' between the public and private sectors, and across UCls}

The relationship between UCIs and the government is characterised as complex and dynamic. ${ }^{13}$ The 'revolving door' phenomenon is one where individuals will move from the public to the private sector and vice versa, in various capacities, so that industry is able to acquire inside information on how policy works and gain privileged access to policy fora; conversely, private actors are recruited into public service posts and can then help make public policy. ${ }^{13} 58$ The anticorruption organisation Transparency International explains that this works to 'undermine trust in government, because of the potential for real or perceived conflicts of interests brought about by the risk of clouded judgements and actions motivated by the prospect of future careers, either in public office or in the private sector. ${ }^{59}$

One example of this phenomenon is a former directorgeneral of the WHO who, having previously publicly defended the WHO publication of evidence-based sugar intake guidelines ${ }^{60}$ against direct threats from The Sugar Association to lobby Congress to remove US funding to the $\mathrm{WHO},{ }^{61}$ took a role as consultant to PepsiCo. ${ }^{62}$ During the same period, the executive director responsible for the prevention of chronic disease, and an early champion of the Framework Convention for Tobacco Control, also followed his WHO tenure with a spell at PepsiCo. Supported by a 12-year funding commitment from Philip Morris International of $\$ 1$ billion, he then launched the Foundation for a Smoke-Free World in supporting 'tobacco harm reduction' and identifying alternative livelihoods for tobacco farmers. ${ }^{63}$ Additional examples include the chief executive of the UK Wine and Spirit Trade Association having previously been deputy director of European Union Affairs and International Agriculture Policy within the Department for Environment, Food and Rural Affairs. ${ }^{64}$ Moreover, in the context of the UK Department of Health's Public Health Responsibility Deal (RD), a public-private partnership with the food, alcohol and other industries in England, with the stated goal of improving health, ${ }^{65}$ the UK Government Cabinet Office official formerly responsible for the RD alcohol network then took on a leadership role in the Portman Group, a UK body representing the alcohol industry, and with The International Alliance for Responsible Drinking, the industry's global social aspects and public relations organisation. Such behaviour may have contributed to the RD including measures which were largely ineffective 
(and would have been known to be in advance, based on the evidence at the time). ${ }^{667}$ The US provides a range of examples of the 'revolving door' between the public and private sectors, ${ }^{68}$ including a Center for Science in the Public Interest lawyer moving to become a lobbyist for The Sugar Association. ${ }^{69}$ A recent study on the 'revolving door' in Australia found that a significant proportion of lobbyists were previously government representatives, citing several examples of government employees going to work directly for alcohol, food or gambling industries, often in roles directly related to their previous employment in government. ${ }^{70}$

\section{Commonalities of corporate political strategies across UCls}

As illustrated in the table 1 below, UCIs commonly employ a range of CPAs, most notably shaping the evidence, framing techniques, constituency building and policy substitution, to promote their interests within public health policy debates. The following section elaborates on commonalities of CPAs across UCIs.

UCIs often use common resources to help shape the narrative about their products and behaviours and to protect their interests, including the same legal, public relations and marketing firms, as well as think-tanks and lobbyists $^{71}{ }^{72}$; examples of the latter include authors of publications attempting to discredit the evidence underpinning harms related to, and regulation required to control, gambling, ${ }^{73}$ food,${ }^{7475}$ tobacco $^{7677}$ and alcohol. ${ }^{78}$

UCIs join forces to promote non-regulatory initiatives ${ }^{38}$ which might include financial or non-financial transactions. Common examples include self-regulation codes, such as the UK Code of Non-Broadcast Advertising, Sales Promotion and Direct Marketing which covers alcohol and e-cigarette marketing, ${ }^{79}$ and the Australian Advertising Standards Bureau and Association of National Advertisers and related organisations (alcohol, food and gambling), including a self-regulation code on gambling advertising and aspects of alcohol promotion. ${ }^{80}$

UCIs also align their efforts in forming alliances with other sectors, organisations or the public to create an appearance of larger support for industry's position. 384045 This is commonly done through the promotion and sponsoring of efforts beyond the core or immediate business. For example, most UCIs have environmental sustainability programmes or commitments, and though many businesses have made significant changes toward environmentally sustainable working and production practices, the mission of sustainability is now also about market advantage ${ }^{81}{ }^{82}$ : as explained in a recent Massachusetts Institute of Technology study about 'eco-business', 'when sustainability burst onto the scene $(\ldots)$ it was in the responsibility category $(. .$. but now it is equally about saving money. ${ }^{81}$ UCIs either create or voluntarily join existing sustainability initiatives; one such example is the CEO Water Mandate, a water stewardship commitment platform for business leaders asking them to voluntarily commit to six action areas, including contributing to public policy.
The CEO Water Mandate is established by the UN's Global Compact, itself criticised for compromising the integrity of the UN by using corporate engagement as an instrument of global governance. ${ }^{83}$ The Mandate's Steering Committee includes ABInBev (alcohol), Nestlé (food), Broken Hill Proprietary Company (mining and petroleum) and Dow Chemicals. Global initiatives are supported by industry-specific strategies, such as International Game Technology's (a word leading gambling company) sustainability strategy, ${ }^{84}$ multinational alcoholic beverage company Diageo's Water Stewardship Strategy ${ }^{85}$ food giant Nestlé's Water Policies and Stewardship $^{86}$ and British American Tobacco's commitment to environmental sustainability. ${ }^{87}$

UCIs also shape scientific processes, often resulting in the production of misinformation, research agendas favourable to their interests and subtle influencing of the scientific evidence ${ }^{38}$; often through mechanisms such as the provision of academic funding, sponsorship or scholarship programmes. Thus SpiritsEUROPE, an organisation supporting the interests of the European alcoholic spirits sector, claims explicitly that 'to control the science agenda is to (partly) influence the policy agenda'. ${ }^{88}$ Other examples include UCI coalitions with research funding councils, such as a coalition of major food and beverage industries and UK Research Councils entitled the Diet and Health Research Industry Club, jointly financing nutrition research ${ }^{89}$ : the industry partners provide only $10 \%$ of the funding but shape the research agenda to their advantage. Supportive researchers are also invited to play down adverse health effects of unhealthy products in scientific publications by, for example, writing rebuttals of research that might harm industry interests. ${ }^{2}$ Thus a researcher was offered $£ 10000$ by the gambling industry to report that gambling problem was a minor issue. ${ }^{233}$ Philip Morris' former Worldwide Scientific Affairs Program spent about US $\$ 200$ million to fund medical schools to conduct research on tobacco smoking ${ }^{90}$; the programme was closed in 2007, but the tobacco industry continues to influence research, such as via the RJ Reynolds Chair of Medicine at Duke University, funded by the RJ Reynolds tobacco company. ${ }^{91}$ The alcohol industryfunded Foundation for Advancing Alcohol Responsibility sponsors a $\$ 3.3$ million endowed chair at Harvard Medical School's Cambridge Health Alliance. ${ }^{92}$

UCIs often exploit narratives of a suboptimal evidence base to undermine, and create doubt about, public health interventions that have been shown to be effective by demanding forms of causal proof that are not possible to achieve in public health. ${ }^{93} 94$ The best known example is the tobacco industry's decade-long attempt to undermine the evidence on smoking and cancer, by calling for ever stronger causal evidence, for instance from randomised trials, when no such evidence could be produced ethically. Similar strategies can also be seen by other industries, including gambling, food and alcohol, which advance the idea that the complexity of the causes of public health problems is such that the 


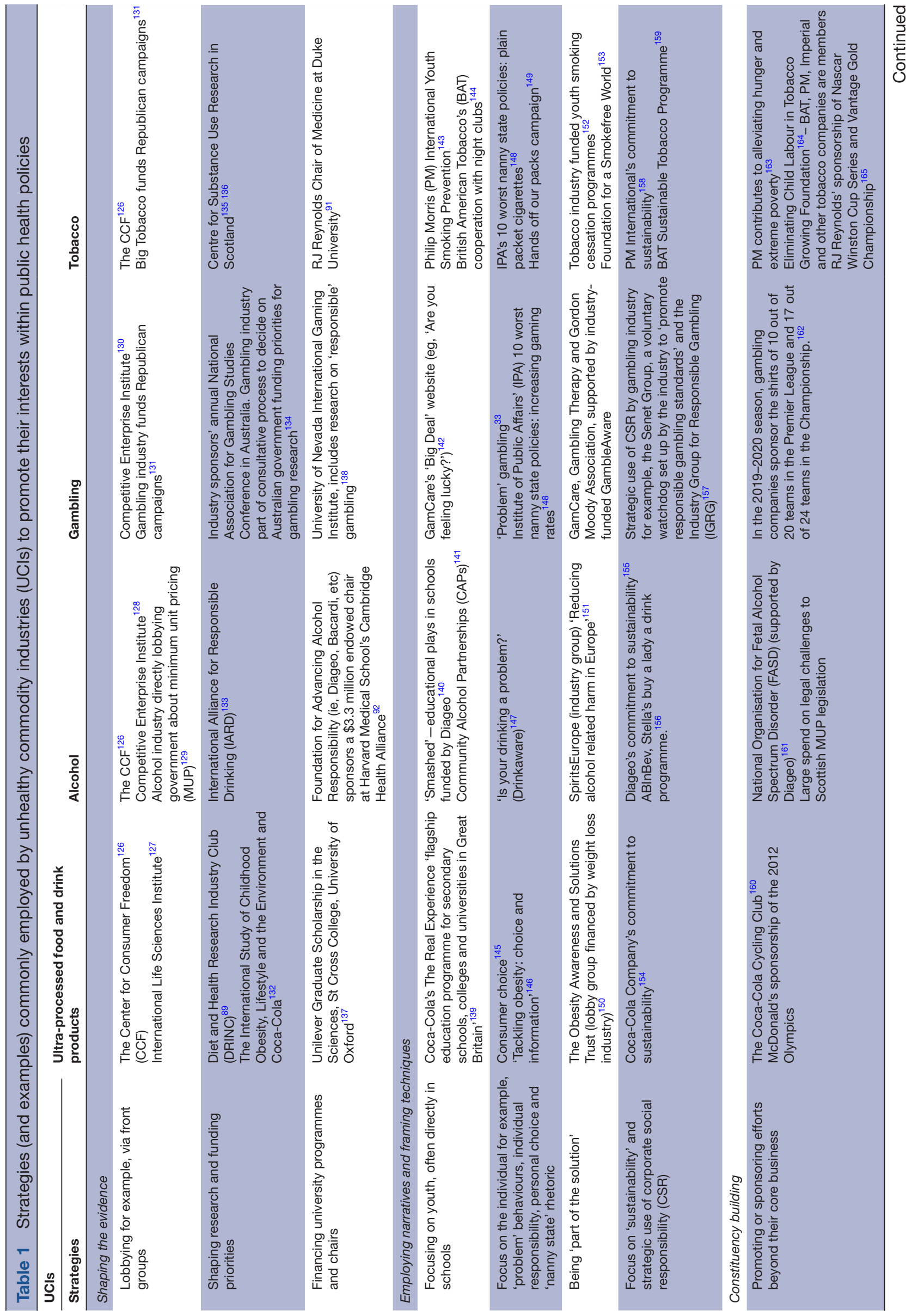




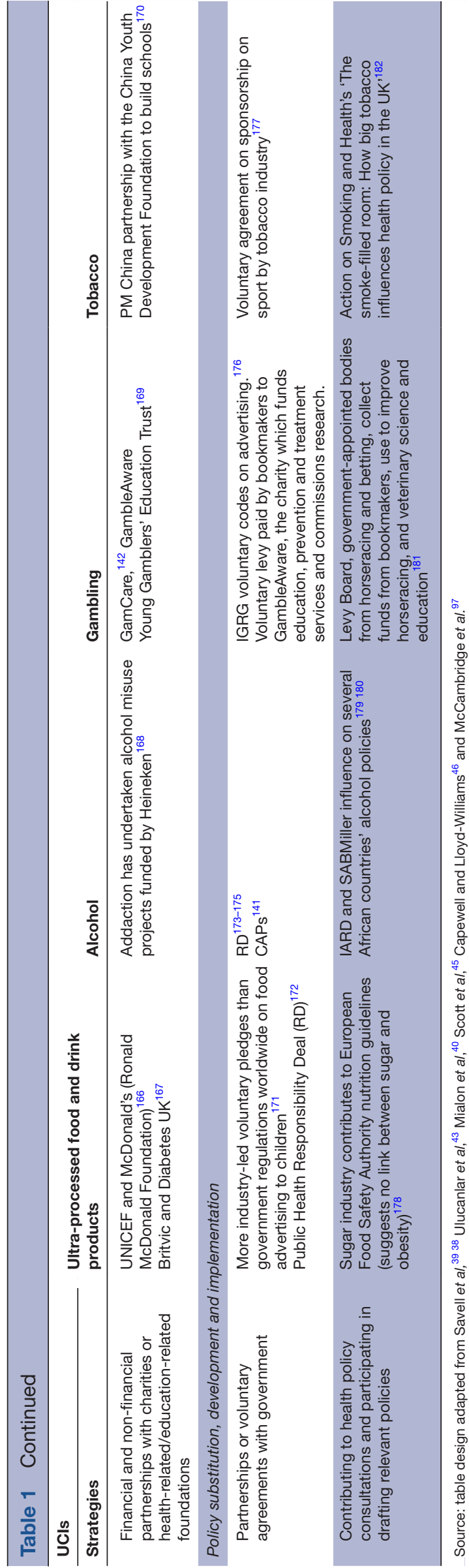

correct solutions are sufficiently unclear that nothing can or should be done until more and better evidence is produced..$^{95} 96$

Table 1 uses the taxonomies of CPA $\mathrm{CP}^{38-40434546}$ to code examples of CPA across UCIs.

\section{DISCUSSION}

There are clear commonalities across UCIs' strategies in their attempts to shape policy-relevant evidence, promote favourable policy narratives, frame debates, and engage in constituency building and policy substitution. Our findings support existing studies in demonstrating strong business links across different UCIs, complex inter-relationships between UCIs and public sector actors which lead to UCI engagement in policy-making forums, and clear commonalities in CPA employed across UCIs. ${ }^{438} 39$ 97-101

Our study echoes others in calling for a unified approach to research on UCIs ${ }^{25} 36102$ and argues for a complex systems approach to analyse the linkages between UCIs and the way in which they collectively influence policy. ${ }^{103}$ Complex systems thinking has long been recommended as a powerful tool for the analysis of UCIs, but has been underused to date. ${ }^{104}$ It allows for the impact of UCIs on health to be conceived not so much as an aggregation of individual 'choices' but more a result of the interactions between diverse actors, factors and their environments. ${ }^{29} 105$ This entails acknowledging that UCIs' actions, and interactions between them, are greater than the sum of their parts, producing change across the system. ${ }^{3167103}$

A systems approach provides tools to help understand how a system is functioning, and what might be the leverage points at which to make desired changes. ${ }^{106}$ Given that the drivers of public health governance are shaped by broad political, institutional, economic and cultural factors, such a methodology can encompass the numerous, varied actors involved, the dynamism and non-linearity of behaviour and effect, and the impact of feedback in the system. It encourages the investigation of complex research questions, ${ }^{107}$ including: What are the intended and unintended consequences of UCIs' efforts? What effects emerge from interactions between UCIs to affect policy change, and how do the effects change over time, and why? Are the effects of cross-UCI influences over policy supported or suppressed by other aspects of the system? Operationalising such research could, in the first instance, include generating causal loop diagrams $^{3167}$ and social network analyses ${ }^{108}$ to capture the range of actors involved, the connections between them and the pathways through which they influence public health-related policy-making. Such research could lead to the development of a theoretical framework for understanding and studying UCIs, individually and collectively; for conducting comparative research across industries and settings; and for analysing the role of UCIs 
in shaping public health policy processes, content and evidence use in public health policy.

Adopting a complex systems approach, partnered with an understanding of the interplay and links between industries and their strategies, reduces the risk of siloed working. It can elucidate ways in which public health actions taken to address specific industry strategies can potentially lead to changes in others parts of the system and industry behaviour that ultimately undermine any benefits intended to be gained from that initial public health intervention.

The risk of conflict of interest emerging from the involvement of UCIs in public health is considerable and complex. Thus the study of how to mitigate conflict of interests related to UCI engagement in public health would also benefit from a complex systems approach. ${ }^{71}$ 109-112 This allows moving away from the predominantly individualistic lens, such as how a person's financial interests might affect their decision-making. ${ }^{113} 114$ While individual risks should also be managed, a complex systems approach allows for more fundamental questions to be explored, including the institutional or structural implications of conflicts between the interests of UCIs and health goals. ${ }^{114}$ Interactions between public health policy stakeholders and UCIs carry systemic risks, including bias in research priorities and conduct, and interpretation of findings, leading to ineffective or delayed public health policy. ${ }^{89}$ 115-119 Many agencies and individuals, including researchers, do not adequately recognise the risks of these interactions and few have policies in place to reduce them. Where UCIs are involved in areas of research or policy relevant to their interest, such as supply chains or implementation of market controls, effective safeguards are needed to manage conflict in the agendas. ${ }^{109114120}$ Again, here, a systems approach can provide a way of conceptualising these multiple factors, actors and interactions.

This analysis has also shown that there is a shared strategy across UCIs to shape both scientific evidence and narratives about a sub-optimal public health evidence base, to suit their interests. The production of evidence should therefore be supported by procedures that render public health policy-making more transparent and less subject to these tactics. ${ }^{121}$ To support this, a broader conception of what constitutes 'good' or 'good enough' evidence in this field is required, one which embraces a wider range of research. This will require the integration of mixed methods from diverse sources and disciplines including quantitative and qualitative traditions ${ }^{31}$ to provide insight into UCI engagement in public health policy-making, and into how networks across sectors create the circumstances under which public health and political actors operate. ${ }^{122-124}$ Innovative methods such as framing analysis of social media would be useful for tracing the trajectory of policy ideas, and investigating concepts such as 'responsibility', 'moderation' and 'nanny state', and how they are transmitted through policy communities of interest. $^{32}$
Finally, it is important to emphasise that this approach does not obviate the need for single-commodity industry research. Rather, researchers need to be comfortable at both levels, and to be mindful of the need to compare and contrast findings to evidence of UCI activity within and across topics. Single-industry enquiry can elucidate fissures and differences in strategy both between and within industries, that may be important to understand in order to achieve public health gains. Further, there will always be a need to evaluate policies which apply to a single commodity, because these are particularly well understood and exploited by UCIs ${ }^{125}$ and because of the likelihood that controls on one commodity may positively or negatively influence use of another. A cross-UCI programme of research would support single UCI research as well as encouraging greater recognition of the commonalities of corporate strategies.

The policy implications of the research reported here include the need for: clarity on processes and governance structures of public health policies; frameworks to understand the nature of relationships and accountability among policymakers or others influencing policy; guidelines and tools to gauge the extent to which the stated primary public health aims of policies may be compromised by corporate political strategies for example, as a result of explicit or hidden conflicts of interest; and ultimately more effective public health policy mechanisms. ${ }^{32}$

\section{CONCLUSION}

The global NCD epidemic is largely driven by the consumption of harmful commodities such as alcohol, tobacco, gambling and UPP. There is conspicuous consistency across the UCIs that produce, promote and sell these goods employing corporate political strategies to maintain commercial interests through their involvement in public health policy-making. Given the magnitude of the NCD challenge and the similarity of strategies employed by UCIs, there is a strong rationale for researchers to investigate the links between these industries more systematically, taking a systems approach to do so. A convergent strategy taking a systems approach to research across UCIs is required to deepen shared understanding of this complex and interconnected area and also to inform a more effective and coherent response. Understanding common processes will allow for the identification and implementation of more effective interventions to regulate and manage the activities of UCIs. Taking a systems approach to conduct cross-UCI, multinational comparative analyses using appropriate and rigorous methodologies across a range of disciplines will also provide the opportunity for enhancing and supporting analyses of individual industries in single countries. Such an endeavour will not only deepen collective understanding of this complex area but also inform the development of more effective public policies related to one of the principal public health challenges in the world. 


\section{Author affiliations}

${ }^{1}$ Faculty of Public Health and Policy, London School of Hygiene \& Tropical Medicine, London, UK

${ }^{2}$ SPECTRUM Consortium, UK

${ }^{3}$ Department of Public Health, Policy \& Systems, University of Liverpool, Liverpool, UK

${ }^{4}$ Department of Anthropology, Goldsmiths University of London, London, UK

${ }^{5}$ Global Public Health Unit, University of Edinburgh, Edinburgh, UK

${ }^{6}$ Population Health Innovation Lab, Department of Public Health, Environments \&

Society, London School of Hygiene \& Tropical Medicine, London, UK

${ }^{7}$ Faculty of Social Sciences, University of Ottawa, Ottawa, Ontario, Canada

${ }^{8}$ Institute for Social Marketing and Health, University of Stirling, Stirling, UK

${ }^{9}$ Tobacco Control Research Group, Department for Health, University of Bath, Bath, UK

${ }^{10}$ Institute of Food and Resource Economics, University of Copenhagen,

Frederiksberg, Denmark

${ }^{11} \mathrm{MRC} / \mathrm{CSO}$ Social and Public Health Sciences Unit, University of Glasgow School of Life Sciences, Glasgow, UK

${ }^{12}$ School of Public Health, Boston University, Boston, Massachusetts, USA

${ }^{13}$ Our Planet Our Health, Wellcome Trust, London, UK

${ }^{14}$ Health Promotion and Community Health, American University of Beirut, Beirut, Lebanon

${ }^{15}$ School of Psychology, University of Birmingham, Birmingham, UK

${ }^{16}$ King's College London, London, UK

${ }^{17}$ Department of Social and Policy Sciences, University of Bath, Bath, UK

${ }^{18}$ Center for International Health Protection, Robert Koch Institute, Berlin, Germany

Twitter Nason Maani @spidermaani

Contributors CK developed and led the research concept, methods, analysis, writing and editing, with support from MP, SC, RC, SC, EE, PF, BH, JDJ, SVK, NM, MM, JFO and HW. JC, NMF, ABG, NMH, RN, HR, NS and MCIVS contributed to the writing and editing.

Funding The 2016 international meeting of researchers was funded by a Wellcome Trust Small Grant in Humanities and Social Sciences (PI CK). JC, ABG, CK, MP and NF are supported by the UK Prevention Research Partnership (MR/ S037519/1), which is funded by the British Heart Foundation, Cancer Research UK, Chief Scientist Office of the Scottish Government Health and Social Care Directorates, Engineering and Physical Sciences Research Council, Economic and Social Research Council, Health and Social Care Research and Development Division (Welsh Government), Medical Research Council, National Institute for Health Research, Natural Environment Research Council, Public Health Agency (Northern Ireland), The Health Foundation and Wellcome. NM is supported by a Harkness Fellowship from the Commonwealth Fund. SVK is funded by an NRS Senior Clinical Fellowship (SCAF/15/02), the Medical Research Council (MC UU 12017/13) and Scottish Government Chief Scientist Office (SPHSU13). MCIVS is funded by an NIHR Doctoral Fellowship (Ref NIHR300156).

Disclaimer The views presented here are those of the authors and should not be attributed to the above funding organisations, their directors, officers or staff.

Competing interests None declared.

Patient and public involvement Patients and/or the public were not involved in the design, or conduct, or reporting, or dissemination plans of this research.

Patient consent for publication Not required.

Provenance and peer review Not commissioned; externally peer reviewed

Data availability statement № data are available. Not applicable.

Open access This is an open access article distributed in accordance with the Creative Commons Attribution Non Commercial (CC BY-NC 4.0) license, which permits others to distribute, remix, adapt, build upon this work non-commercially, and license their derivative works on different terms, provided the original work is properly cited, appropriate credit is given, any changes made indicated, and the use is non-commercial. See: http://creativecommons.org/licenses/by-nc/4.0/.

\section{ORCID iDs}

Cécile Knai http://orcid.org/0000-0001-6663-7379

Nason Maani http://orcid.org/0000-0002-3398-0688

\section{REFERENCES}

1 World Health Organization. Noncommunicable diseases. fact sheet. Geneva: World Health Organization, 2018.
2 Cassidy R. How Corporations Shape our Understanding of Problems with Gambling and their Solutions. In: Kenworthy N, MacKenzie R, Lee K, eds. Case studies on corporations and global health governance impacts, influence and accountability. London: Rowman and Littlefield, 2016.

3 The Lancet. Problem gambling is a public health concern. The Lancet 2017;390:913.

4 Stuckler D, McKee M, Ebrahim S, et al. Manufacturing epidemics: the role of global producers in increased consumption of unhealthy commodities including processed foods, alcohol, and tobacco. PLoS Med 2012;9:e1001235.

5 GBD 2016 Alcohol and Drug Use Collaborators. The global burden of disease attributable to alcohol and drug use in 195 countries and territories, 1990-2016: a systematic analysis for the global burden of disease study 2016. Lancet Psychiatry 2018;5:987-1012.

6 Melaku YA, Renzaho A, Gill TK, et al. Burden and trend of dietrelated non-communicable diseases in Australia and comparison with 34 OECD countries, 1990-2015: findings from the global burden of disease study 2015. Eur J Nutr 2019;58:1299-313. doi:10.1007/s00394-018-1656-7

7 Sulkunen P, Babor T, Cisneros Ornberg J, et al. Setting limits. Gambling, Science and Public Policy: Oxford University Press, 2018.

8 Latvala T, Lintonen T, Konu A. Public health effects of gambling debate on a conceptual model. BMC Public Health 2019;19:1077.

9 Afifi TO, Nicholson R, Martins SS, et al. A longitudinal study of the temporal relation between problem gambling and mental and substance use disorders among young adults. Can J Psychiatry 2016;61:102-11.

10 Markham F, Young M, Doran B. The relationship between player losses and gambling-related harm: evidence from nationally representative cross-sectional surveys in four countries. Addiction 2016;111:320-30

11 World Health Organization. UN high-level meeting on NCDS: summary report of the discussions at the round tables, 2011.

12 Freudenberg N. Lethal but Legal. Corporations, consumption, and protecting public health. New York: Oxford University Press, 2014

13 Miller D, Harkins C, strategy C. Corporate strategy, corporate capture: food and alcohol industry lobbying and public health. Crit Soc Policy 2010;30:564-89.

14 Carlson V, Chilton MJ, Corso LC, et al. Defining the functions of public health governance. Am J Public Health 2015;105:S159-66.

15 Farnsworth K, Holden C. The Business-Social policy nexus: corporate power and corporate inputs into social policy. J Soc Policy 2006;35:473-94.

16 Dahl R. Who governs?: democracy and power in the American City (Yale studies in political science. 2nd Edn. Yale University Press, 1961.

17 Oxfam. The world's top 100 economies: 31 countries, 2016. Available: https://oxfamblogs.org/fp2p/the-worlds-top-100economies-31-countries-69-corporations/

18 Smith KE, Fooks G, Collin J, et al. Is the increasing policy use of impact assessment in Europe likely to undermine efforts to achieve healthy public policy? J Epidemiol Community Health 2010;64:478-87.

19 Smith KE, Fooks G, Collin J, et al. "Working the system"--British American tobacco's influence on the European union treaty and its implications for policy: an analysis of internal tobacco industry documents. PLoS Med 2010;7:e1000202.

20 Smith KE, Fooks G, Gilmore AB, et al. Corporate Coalitions and Policy Making in the European Union: How and Why British American Tobacco Promoted "Better Regulation". J Health Polit Policy Law 2015;40:325-72.

21 Hatchard JL, Fooks GJ, Gilmore AB. Standardised tobacco packaging: a health policy case study of corporate conflict expansion and adaptation. BMJ Open 2016;6:e012634.

22 Ulucanlar S, Fooks GJ, Hatchard JL, et al. Representation and misrepresentation of scientific evidence in contemporary tobacco regulation: a review of tobacco industry submissions to the UK government consultation on standardised packaging. PLoS Med 2014;11:e1001629.

23 Maani N, Collin J, Friel S, et al. Bringing the commercial determinants of health out of the shadows: a review of how the commercial determinants are represented in conceptual frameworks. Eur J Public Health 2020;30:660-4.

24 Kickbusch I, Allen L, Franz C. The commercial determinants of health. Lancet Glob Health 2016;4:e895-6.

25 de Lacy-Vawdon C, Livingstone C. Defining the commercial determinants of health: a systematic review. BMC Public Health 2020;20:1022. 
26 Collin J, Plotnikova E, Hill S. One unhealthy commodities industry? understanding links across tobacco, alcohol and ultra-processed food manufacturers and their implications for tobacco control and the SDGS. Tob Induc Dis 2018;16:A80.

27 Hilton S, Buckton CH, Henrichsen T, et al. Policy congruence and advocacy strategies in the discourse networks of minimum unit pricing for alcohol and the soft drinks industry levy. Addiction 2020;115:2303-14.

28 Lee BY, Bartsch SM, Mui Y, et al. A systems approach to obesity. Nutr Rev 2017;75:94-106.

29 Rutter H, Savona N, Glonti K, et al. The need for a complex systems model of evidence for public health. Lancet 2017;390:2602-4.

30 Midgley G. Systemic intervention for public health. Am J Public Health 2006;96:466-72.

31 Knai C, Petticrew M, Mays N, et al. Systems thinking as a framework for analyzing commercial determinants of health Milbank Q 2018;96:472-98.

32 Knai C. End of grant report. Wellcome Trust, Small Grant, Society and Ethics Meeting, "Evaluation of the Public Health Responsibility Deal in England: A conference for knowledge translation and exchange", 2016.

33 Cassidy R, Loussouarn C, Pisac A. Fair game: producing gambling research. The Goldsmiths report, 2013. Available: http://www.gold. ac.uk/media/documents-by-section/departments/anthropology/ Fair-Game-Web-Final.pdf

34 Thomas SL, David J, Randle M, et al. Gambling advocacy: lessons from tobacco, alcohol and junk food. Aust N Z J Public Health 2016;40:211-7.

35 Dorfman L, Cheyne A, Friedman LC, et al. Soda and tobacco industry corporate social responsibility campaigns: how do they compare? PLoS Med 2012;9:e1001241.

36 Smith K, Dorfman L, Freudenberg N, et al. Tobacco, alcohol, and processed food industries - why do public health practitioners view them so differently? Front Public Health 2016;4.

37 Knai C, James L, Petticrew M, et al. An evaluation of a publicprivate partnership to reduce artificial trans fatty acids in England, 2011-16. Eur J Public Health 2017;27:605-8.

38 Savell E, Fooks G, Gilmore AB. How does the alcohol industry attempt to influence marketing regulations? A systematic review. Addiction 2016;111:18-32.

39 Savell E, Gilmore AB, Fooks G. How does the tobacco industry attempt to influence marketing regulations? A systematic review. PLoS One 2014;9:e87389.

40 Mialon M, Swinburn B, Sacks G. A proposed approach to systematically identify and monitor the corporate political activity of the food industry with respect to public health using publicly available information. Obes Rev 2015;16:519-30.

41 Hawkins B, Holden C, Eckhardt J, et al. Reassessing policy paradigms: a comparison of the global tobacco and alcohol industries. Glob Public Health 2018;13:1-19.

42 Hillman AJ, Keim GD, Schuler D. Corporate political activity: a review and research agenda. J Manage 2004;30:837-57.

43 Ulucanlar S, Fooks GJ, Gilmore AB. The policy Dystopia model: an interpretive analysis of tobacco industry political activity. PLoS Med 2016;13:e1002125.

44 Hancock L, Ralph N, Martino FP. Applying corporate political activity (Cpa) analysis to Australian gambling industry submissions against regulation of television sports betting advertising. PLOS One 2018;13:e0205654.

45 Scott C, Hawkins B, Knai C. Food and beverage product reformulation as a corporate political strategy. Soc Sci Med 2017;172:37-45.

46 Capewell S, Lloyd-Williams F. The role of the food industry in health: lessons from tobacco? Br Med Bull 2018;125:131-43.

47 Bond L, Daube M, Chikritzhs T. Selling addictions: similarities in approaches between big tobacco and big booze. Australas Med $\mathrm{J}$ 2010;3:325-32

48 Bond L, Daube M, Chikritzhs T. Access to Confidential Alcohol Industry Documents: From 'Big Tobacco' to 'Big Booze'. Australas Med J 2009;1:1-26.

49 Collin J. Tobacco control, global health policy and development: towards policy coherence in global governance. Tob Control 2012;21:274-80.

50 Nguyen KH, Glantz SA, Palmer CN, et al. Tobacco industry involvement in children's sugary drinks market. $B M J$ 2019;364:1736.

51 Moodie R, Stuckler D, Monteiro C, et al. Profits and pandemics: prevention of harmful effects of tobacco, alcohol, and ultraprocessed food and drink industries. Lancet 2013;381:670-9.
52 IOGT International. Tobacco giant Altria gains profits from ab InBev, 2017. Available: http://iogt.org/news/2017/08/26/tobacco-giantaltria-gains-profits-ab-inbev/

53 Institute of Alcohol Studies. Constituency building, 2017. Available: http://www.ias.org.uk/Alcohol-knowledge-centre/The-alcoholindustry/Factsheets/Constituency-building.aspx\#_edn12

54 Reuters. Stocks - Anheuser Busch Inbev NV (ABI.BR)". Reuters Business. Thomson Reuters, 2017. Available: https://uk.reuters. $\mathrm{com} /$ business/stocks/overview/ABI.BR

55 Altria. Altria to make growth investment in Cronos group, 2018. Available: http://investor.altria.com/file/Index?KeyFile=396027308

56 Sweet M. The unhealthy trifecta: tobacco, alcohol and gambling industries, 2012. Available: https://blogs.crikey.com.au/croakey/ 2012/04/19/the-unhealthy-trifecta-tobacco-alcohol-and-gamblingindustries/

57 Mizruchi MS. What do Interlocks do? an analysis, critique, and assessment of research on interlocking Directorates. Annu Rev Sociol 1996;22:271-98.

58 TobaccoTactics. Revolving door, 2019. Available: https:// tobaccotactics.org/wiki/revolving-door-d79/

59 Transparency International. Access all areas when EU politicians become lobbyists, 2014.

60 WHO. Diet, nutrition and the prevention of chronic diseases. technical report series 916. Geneva: World Health Organization, 2003.

61 Briscoe A. Letter from The Sugar Assocation in response to the WHO technical report 916 on "Diet, Nutrition and The Prevention of Chronic Disease": The Sugar Association, 2003.

62 Aftenposten. Gro får kritikk for å være Pepsi-rådgiver (Gro get criticised for becoming an adviser to Pepsi), 2007. Available: https://www.aftenposten.no/norge/i/6kOdo/Gro-far-kritikk-for-avare-Pepsi-radgiver

63 van der Eijk Y, Bero LA, Malone RE. Philip Morris Internationalfunded 'Foundation for a Smoke-Free World': analysing its claims of independence. Tob Control 2019;28:712-8.

64 Miller D, Harkins C. Revolving doors and alcohol policy: a cautionary tale, 2013. Available: https://www.alicerap.eu/blog/120revolving-doors-and-alcohol-policy-a-cautionary-tale.html

65 Department of Health. The public health responsibility deal, 2014. Available: https://responsibilitydeal.dh.gov.uk/

66 Knai C, Petticrew M, Durand MA, et al. The public health responsibility deal: has a public-private partnership brought about action on alcohol reduction? Addiction 2015;110:1217-25.

67 Knai C, Petticrew M, Douglas N, et al. The public health responsibility deal: using a Systems-Level analysis to understand the lack of impact on alcohol, food, physical activity, and workplace health Sub-Systems. Int J Environ Res Public Health 2018;15:2895.

68 Watson E. Chobani hires man behing MyPlate as senior director for nutrition \& regulatory affairs, 2014. Available: http://www. foodnavigator-usa.com/People/Chobani-hires-Dr-Robert-Post-innutrition-regulatory-affairs-role

69 Nestle M. The revolving door: from CSPI to the sugar association? 2015. Available: https://www.foodpolitics.com/2015/10/therevolving-door-from-cspi-to-the-sugar-association/

70 Robertson NM, Sacks G, Miller PG. The revolving door between government and the alcohol, food and gambling industries in Australia. Public Health Res Pract 2019;29:e2931921.

71 Adams J, Jeopardy M. Risks of accepting money from the alcohol, tobacco and gambling industries. Cambridge: Cambridge University Press, 2016.

72 Jiang N, Ling P. Vested interests in addiction research and policy. alliance between tobacco and alcohol industries to shape public policy. Addiction 2013;108:852-64.

73 Basham P, Luik J. The social benefits of gambling. Economic Affairs 2011;31:9-13.

74 Basham P, Luik J. A happy meal ban is nothing to SMILE about, 2010. Available: http://www.spiked-online.com/newsite/article/ 9871\#.Vryp0FI8rQM

75 Basham P, Luik J. Is the obesity epidemic exaggerated? Yes. BMJ 2008:336:244.

76 Basham P, Luik J. Displaying their ignorance on smoking. Washington: Cato Institute, 2009. https://www.cato.org/ publications/commentary/displaying-their-ignorance-smoking

77 Basham P. An absence of tobacco evidence. Washington: Cato Institute, 2009. https://www.cato.org/publications/commentary/ absence-tobacco-evidence

78 Basham P, Luik J. Banning alcohol ads won't cure alcoholism. Spiked, 2009. Available: https://www.spiked-online.com/2009/07/ 21/banning-alcohol-ads-wont-cure-alcoholism/

79 Advertising Standards Authority. The CAP Code. The UK Code of Non-broadcast Advertising and Direct \& Promotional Marketing. 
Edition 12. V12.2.15, 2015. Available: https://www.asa.org.uk/ asset/47EB51E7-028D-4509-AB3C0F4822C9A3C4/

80 AANA. AANA Wagering Advertising \& Marketing Communication Code, 2016. Available: http://aana.com.au/content/uploads/2016/ 05/Wagering_Advertising_Marketing_Communications_Code.pdf

81 Dauvergne P, Lister J. Eco-Business: a big-brand takeover of sustainability. Cambridge: the MIT Press, 2013.

82 Portney K. Sustainability. Cambridge: The MIT Press, 2015

83 Knight G, Smith J. The Global Compact and Its Critics: Activism, Power Relations, and Corporate Social Responsibility. In: Discipline and punishment in global politics. New York: Palgrave Macmillan, 2008.

84 International Game Technology. Ahead of the game. IGT sustainability report, 2020. Available: https://www.igt.com/exploreigt/about-igt/global-responsibility/sustainability-report

85 Diageo. Water stewardship, 2020. Available: http://www.diageo. com/en-row/csr/environment/Pages/water-stewardship.aspx

86 Nestle company. Water policies and stewardship. our commitment: advocate for effective water policies and stewardship, 2020. Available: http://www.nestle.com/csv/planet/ policy-stewardship

87 British American Tobacco. Sustainability, 2020. Available: http:// www.bat.com/sustainability

88 SpiritsEUROPE. Position summary: the body of evidence policymaking and research, 2014. Available: http://spirits.eu/files/22/cp. as-050-2014-the-body-of-evidence.pdf

89 Knai C, Gilmore A, Lock K, et al. Public health research funding: independence is important. The Lancet 2010;376:75-7.

90 Bero LA. Tobacco industry manipulation of research. Public Health Rep 2005;120:200-8.

91 Duke University School of Medicine. R.J. Reynolds Professor of medicine, 2020. Available: https://medicine.duke.edu/faculty/marye-klotman-md

92 Justice A. Spirits producers sponsor Harvard professorship, 2015. Available: https://alcoholjustice.org/watchdogging-2/in-thedoghouse/1154-spirits-producers-sponsor-harvard-professorship

93 Oreskes N, Conway E. Merchants of doubt. Bloomsbury US, 2010.

94 Michaels D. Doubt is Their Product: How Industry's Assault on Science Threatens Your Health. 1st ed. Oxford University Press, 2008.

95 Petticrew M, Katikireddi SV, Knai C, et al. 'Nothing can be done until everything is done': the use of complexity arguments by food, beverage, alcohol and gambling industries. J Epidemiol Community Health 2017;71:jech-2017-209710-83.

96 Savona N, Thompson C, Smith D, et al. 'Complexity' as a rhetorical smokescreen for UK public health inaction on diet. Crit Public Health 2020;13:1-11.

97 McCambridge J, Mialon M, Hawkins B. Alcohol industry involvement in policymaking: a systematic review. Addiction 2018;113:1571-84

98 Moodie R, Stuckler D, Monteiro C, et al. Profits and pandemics: prevention of harmful effects of tobacco, alcohol, and ultra-processed food and drink industries. The Lancet 2013;381:670-9.

99 Gilmore AB, Savell E, Collin J. Public health, corporations and the new responsibility deal: promoting partnerships with vectors of disease? J Public Health 2011;33:2-4.

100 Wiist W. The bottom line or public health: tactics corporations use to influence health and health policy, and what we can do to counter them. Oxford University Press, 2010.

101 Suzuki E, Moon S, Kenworthy N, et al. Informal channels of corporate influence on global health policymaking: A mapping of strategies across four industries. In: Case studies on corporations and global health governance. Lanham, MD: Rowman and Littlefield, 2016.

102 Paichadze N, Werbick M, Ndebele P, et al. Commercial determinants of health: a proposed research agenda. Int J Public Health 2020;65:1147-9.

103 Rutter H, Savona N, Glonti K, et al. The need for a complex systems model of evidence for public health. The Lancet 2017;390:2602-4.

104 Holder H. Alcohol and the Community : a Systems Approach to Prevention. Cambridge University Press, 1998.

105 Petticrew M, Shemilt I, Lorenc T, et al. Alcohol advertising and public health: systems perspectives versus narrow perspectives. $J$ Epidemiol Community Health 2017;71:308-12.

106 Arnold RD, Wade JP. A definition of systems thinking: a systems approach. Procedia Comput Sci 2015;44:669-78.

107 Petticrew M, Knai C, Thomas J, et al. Implications of a complexity perspective for systematic reviews and Guideline development in health decision making. BMJ Glob Health 2019;4:e000899.
108 Weishaar H, Amos A, Collin J. Best of enemies: using social network analysis to explore a policy network in European smokefree policy. Soc Sci Med 2015;133:85-92.

109 UK Health Forum. Improving health through better governance strengthening the governance of diet and nutrition partnerships for the prevention of chronic diseases, 2016.

110 ICARA. International Confederation for Alcohol, Tobacco \& Other Drug Research Associations Guidelines on the Management of Relationships with Organizations with Vested Interests, 2019.

111 Grundy Q, Dunn AG, Bero L. Improving researchers' conflict of interest declarations. BMJ 2020;2:m422.

112 Grundy Q, Mayes C, Holloway K, et al. Conflict of interest as ethical shorthand: understanding the range and nature of "nonfinancial conflict of interest" in biomedicine. J Clin Epidemiol 2020:120:1-7.

113 Marks J. The perils of partnership. industry influence, institutional integrity, and public health. Oxford University Press, 2019.

114 Ralston R, Hil SE, da Silva Gomes F, et al. Towards preventing and managing conflict of interest in nutrition policy? an analysis of submissions to a consultation on a draft who tool. Int $J$ Health Policy Manag 2020. doi:10.34172/ijhpm.2020.52. [Epub ahead of print: 21 Apr 2020].

115 Nestle M. Corporate funding of nutrition research and unjustified Conclusions - Reply. JAMA Intern Med 2016;176:717-8.

116 Bes-Rastrollo M, Schulze MB, Ruiz-Canela M, et al. Financial conflicts of interest and reporting bias regarding the association between sugar-sweetened beverages and weight gain: a systematic review of systematic reviews. PLoS Med 2013;10:e1001578.

117 Grüning T, Gilmore AB, McKee M. Tobacco industry influence on science and scientists in Germany. Am J Public Health 2006;96:20-32.

118 Babor TF, Miller PG, McCarthyism MPG. McCarthyism, conflict of interest and Addiction 's new transparency declaration procedures. Addiction 2014;109:341-4.

119 Katz D, Caplan AL, Merz JF. All gifts large and small: toward an understanding of the ethics of pharmaceutical industry gift-giving. Am J Bioeth 2003;3:39-46.

120 Delfabbro P, King D. Gambling is not a capitalist conspiracy: critical commentary of literature on the 'industry state gambling complex', 2017.

121 Hawkins B, Parkhurst J. The 'good governance' of evidence in health policy. Evid Policy 2016;12:575-92.

122 Cairney P. The politics of evidence-based policy making. Springer, 2016.

123 Cairney P. A 'Multiple Lenses' Approach to Policy Change: The Case of Tobacco Policy in the UK. British Politics 2007;2:45-68.

124 Weishaar H, Amos A, Collin J. Capturing complexity: mixing methods in the analysis of a European tobacco control policy network. Int J Soc Res Methodol 2015;18:175-92.

125 Scott S, Muir C, Stead M, et al. Exploring the links between unhealthy eating behaviour and heavy alcohol use in the social, emotional and cultural lives of young adults (aged 18-25): a qualitative research study. Appetite 2020;144:104449.

126 CCF. The center for consumer freedom, 2020. Available: https:// www.consumerfreedom.com/

127 ILSI. International life sciences Institute, annual report 2019, 2020. Available: https://ilsiweb.s3.amazonaws.com/ilsi/wp-content/ uploads/2020/01/AR/index.html\#18

128 Minton M. Cdc alcohol and pregnancy scare tactics Backfire. competitive enterprise Institute, 2016. Available: https://cei.org/ $\mathrm{blog} / \mathrm{cdc}$-alcohol-and-pregnancy-scare-tactics-backfire

129 Gornall J. Under the influence. BMJ 2014;348:g1166.

130 Minton M. No sports betting should be a crime. Austin American statesman, competitive enterprise Institute, 2015. Available: https:// cei.org/content/minton-no-sports-betting-should-be-crime

131 Steinberg A. lowa.South Carolina: Evangelicals and Trump, 2016. Available: http://www.huffingtonpost.com/arnold-steinberg/ iowasouth-carolina-evange_b_9210648.html

132 Stuckler D, Ruskin G, McKee M. Complexity and conflicts of interest statements: a case-study of emails exchanged between Coca-Cola and the principal Investigators of the International study of childhood obesity, lifestyle and the environment (ISCOLE). $J$ Public Health Policy 2018;39:49-56.

133 IARD. International alliance for responsible drinking, 2016 Available: http://www.iard.org/

134 Thomas A, Vasiliadis S, Deblaquiere J. Australian gambling research priorities. summary findings from consultations conducted by the Australian gambling research centre, 2015. Available: https://aifs.gov.au/agrc/publications/australian-gambling-researchpriorities 
135 CSUR Research and Consultancy. CSUR (centre for substance use research) research and Consultancy, 2019. Available: https://www. csures.com/

136 Tobacco Tactics. Fontem ventures: funding e-cigarette research and harm reduction claims, 2018. Available: http://www. tobaccotactics.org/index.php?title=Fontem_Ventures

137 St Cross College, University of Oxford. Unilever graduate scholarship in the sciences, 2016. Available: http://www. postgraduatefunding.com/award-4156

138 International Gaming Institute. Research. Las Vegas: University of Nevada, 2016.

139 Coca Cola Enterprises Ltd. The real experience, 2016. Available: http://www.therealexperience.co.uk/

140 Diageo. SMASHED - giving UK students the facts about alcohol, 2015. Available: https://www.diageo.com/en/in-society/casestudies/smashed-giving-uk-students-the-facts-about-alcohol/

141 Petticrew M, Douglas N, D'Souza P, et al. Community alcohol partnerships with the alcohol industry: what is their purpose and are they effective in reducing alcohol harms? J Public Health $2017 ; 12$.

142 BigDeal. BigDeal. Feeling lucky slideshow, 2017. Available: https:// www.bigdeal.org.uk/videos/no-way/slideshow_feelinglucky/ GamCare

143 Philip Morris International. Underage tobacco and nicoting use, 2020. Available: https://www.pmi.com/our-views-and-standards/ our-views/underage-tobacco-and-nicotine-use

144 Stanton CR, Chu A, Collin J, et al. Promoting tobacco through the International language of dance music: British American tobacco and the Ministry of sound. Eur J Public Health 2011;21:21-8.

145 Nestle M. Why the 'Consumer Choice' Argument Is an Automatic Win for Big Soda, 2012. Available: http://www.theatlantic.com/ health/archive/2012/07/why-the-consumer-choice-argument-is-anautomatic-win-for-big-soda/259293/

146 Coca Cola Great Britain. Tackling obesity: choice and information, 2020. Available: https://www.coca-cola.co.uk/ingredients/reducingsugar/tackling-obesity-choice-and-information

147 Drinkaware. Examine your drinking, 2020. Available: https://www. drinkaware.co.uk/advice/are-you-drinking-too-much

148 Berg C. Ten worst nanny state policies. Melbourne: Institute of Public Affairs, 2016. https://ipa.org.au/ipa-review-articles/10-worstnanny-state-policies

149 Tobacco Tactics. Hands off our packs, 2020. Available: https:// tobaccotactics.org/wiki/hands-off-our-packs/

150 Gillard M. MPs 'conned' over obesity charity that was front for diet firm. The Independent, 2008. Available: https://www.independent. co.uk/news/uk/politics/mps-conned-over-obesity-charity-that-wasfront-for-diet-firm-771266.html

151 SpiritsEUROPE. Reducing alcohol related harm in Europe, 2020. Available: https://spirits.eu/spirits-society/reducing-alcohol-relatedharm-in-europe

152 Landman A, Ling PM, Glantz SA. Tobacco industry youth smoking prevention programs: protecting the industry and hurting tobacco control. Am J Public Health 2002;92:917-30.

153 Foundation for a smoke-free world, 2019. Available: https://www. smokefreeworld.org/

154 Coca Cola company. Sustainability, 2020. Available: https://www. coca-cola.co.uk/sustainability

155 Diageo. 2020 sustainability and responsibility targets, 2020. Available: https://www.diageo.com/en/in-society/our-role-insociety/2020-sustainability-and-responsibility-targets/

156 AblnBev. Water stewardship. Stella's Buy a Lady a Drink Program, 2019. Available: https://www.ab-inbev.com/news-media/waterstewardship/stellas-buy-a-lady-a-drink-program.html

157 Spilde Contreras K, Siegel D. A case study of the strategic use of CSR: the American Gaming Association and the National Center for Responsible Gaming. In: Mallin C, ed. Corporate social responsibility: case study approach. Cheltenham, UK: Edward Elgar, 2009

158 Philip Morris International. Sustainability, 2020. Available: http:// www.pmi.com/eng/sustainability/pages/sustainability.aspx

159 British American Tobacco. Sustainable tobacco programme. New programme drives industry-wide supplier standards, 2019.
Available: http://www.bat.com/group/sites/UK_9D9KCY.nsf/ vwPagesWebLive/DO9DEEBL

160 Coca Cola cycling Club, 2020. Available: https://www.strava.com/ clubs/25244

161 National organisation for FASD. policies and financial info, 2020. Available: https://nationalfasd.org.uk/about-us/policies-andfinancial-info/

162 Magowan A. Gambling in football: Betting sponsorship on shirts should be banned - Lords report, 2020. Available: https://www.bbc. co.uk/sport/football/53261364

163 Philip Morris International. Giving back, wherever we are, 2020. Available: https://www.pmi.com/sustainability/community/givingback-wherever-we-are

164 ECLT Foundation. Eliminating child labour in tobacco growing, 2019. Available: http://www.eclt.org/

165 Sourcewatch. Tobacco industry sponsorship of sporting events, 2008. Available: https://www.sourcewatch.org/index.php/Tobacco industry sponsorship of sporting events

166 Dyer $\mathrm{O}$. Unicef comes under attack for big MAC funding deal. BMJ 2002;325:923b-923.

167 Britvic. Diabetes UK partnership, 2020. Available: https://www. britvic.com/sustainable-business/healthier-people/diabetes-ukpartnership

168 FT. Business logic behind Heineken alcohol misuse project, 2015. Available: https://www.ft.com/content/5306eaf0-ddfc-11e4-8d1400144feab7de

169 Grierson J. Britain's newest gambling addiction charity funded by betting firms, 2016. Available: https://www.theguardian.com/ society/2016/aug/19/britains-newest-gambling-addiction-charityfunded-industrys-gala-bet365-paddy-power

170 Philip Morris International. Philip Morris China - overview, 2016. Available: http://www.pmi.com/marketpages/pages/market_en_cn. aspx

171 Roberto CA, Swinburn B, Hawkes C, et al. Patchy progress on obesity prevention: emerging examples, entrenched barriers, and new thinking. Lancet 2015;385:2400-9.

172 Knai C, Petticrew M, Durand MA, et al. Has a public-private partnership resulted in action on healthier diets in England? an analysis of the public health responsibility deal food pledges. Food Policy 2015;54:1-10.

173 Knai C, Petticrew M, Durand MA, et al. Are the public health responsibility deal alcohol pledges likely to improve public health? an evidence synthesis. Addiction 2015;110:1232-46.

174 Petticrew M, Douglas N, Knai C, et al. Health information on alcoholic beverage containers: has the alcohol industry's pledge in England to improve labelling been met? Addiction 2016;111:51-5.

175 Hawkins B, McCambridge J. Public-private partnerships and the politics of alcohol policy in England: the Coalition Government's Public Health 'Responsibility Deal'. BMC Public Health 2019;19:1477.

176 BGC. Industry group for responsible gambling, 2020. Available: https://bettingandgamingcouncil.com/igrg/

177 UK Parliament. Memorandum by imperial tobacco group PLC. the tobacco industry and the health risks of smoking (TB 13) cooperation with government, 2000. Available: https://publications. parliament.uk/pa/cm199900/cmselect/cmhealth/27/0011328.htm

178 EUObserver. Sugar industry helped write EU nutrition advice, 2016. Available: https://euobserver.com/tickers/132098

179 Bakke Øystein, Endal D. Vested interests in addiction research and policy alcohol policies out of context: drinks industry supplanting government role in alcohol policies in sub-Saharan Africa. Addiction 2010;105:22-8.

180 Hawkins B, McCambridge J. 'Tied up in a legal mess': The alcohol industry's use of litigation to oppose minimum alcohol pricing in Scotland. Scott Aff 2020;29:3-23.

181 UK Government. Culture Secretary appoints new levy board members, 2015. Available: https://www.gov.uk/government/news/ culture-secretary-appoints-new-levy-board-members

$182 \mathrm{ASH}$. The smoke filled room: how big tobacco influences health policy in the UK, 2010. Available: http://www.ash.org.uk/ SmokeFilledRoom 